\title{
ARCHEOLOGICKÝ VÝSKUM REFORMOVANÉHO KOSTOLA NA ZEMPLÍNSKOM HRADISKU
}

\author{
PETER TAJKOV
}

Abstrakt: Príspevok predkladá výsledky archeologického výskumu kostola reformovanej cirkvi na včasnohistorickom hradisku v obci Zemplín v rokoch 2013 a 2014 v kontexte staršieho archeologického bádania na lokalite. Výskumom bol rekonštruovaný pôdorys jeho najstaršej stavebnej fázy z 12. storočia a d'alšich zaniknutých stavebných etáp.

Kl'účové slová: kostol-Zemplín-hradisko-stredovek.

\section{Archaeological Research into a Reformed Christianity Church at a Hillfort in Zemplín}

Abstract: This contribution presents the results of archaeological research into a reformed Christianity church at an early-medieval hillfort in the village of Zemplin conducted in 2013 and 2014, in the context of earlier research carried out at the location. The research enabled the reconstruction of the ground plan of the church and its oldest building phase in the 12th century, as well as further historical building phases.

Key words: church - Zemplin - hillfort-Middle Ages.

\section{Lokalita - história výskumu - historický kontext}

Kostol reformovanej cirkvi v obci Zemplín sa nachádza na jej východnom okraji, na vyvýšenine zvanej Hradisko, nad pravým brehom rieky Bodrog. Hradisko s nadmorskou výškou vyše $121 \mathrm{~m}$ n.m. má $20 \mathrm{~m}$ prevýšenie nad okolitou krajinou a rozlohu 2,4 ha. Elipsovitý tvar valu má $585 \mathrm{~m}$, jeho výška z vnútornej strany je max. $10 \mathrm{~m}$. Reformovaný kostol stojí približne v jeho strede (obr. 1). V severnom susedstve skúmanej stavby stojí d’alší chrám patriaci gréckokatolíckej cirkvi, postavený na začiatku 19. storočia (Súpis 1969, 467). Vel'kú čast' bývalej opevnenej plochy dnes pokrýva cintorín, na ktorom sa len nedávno prestalo pochovávat'.

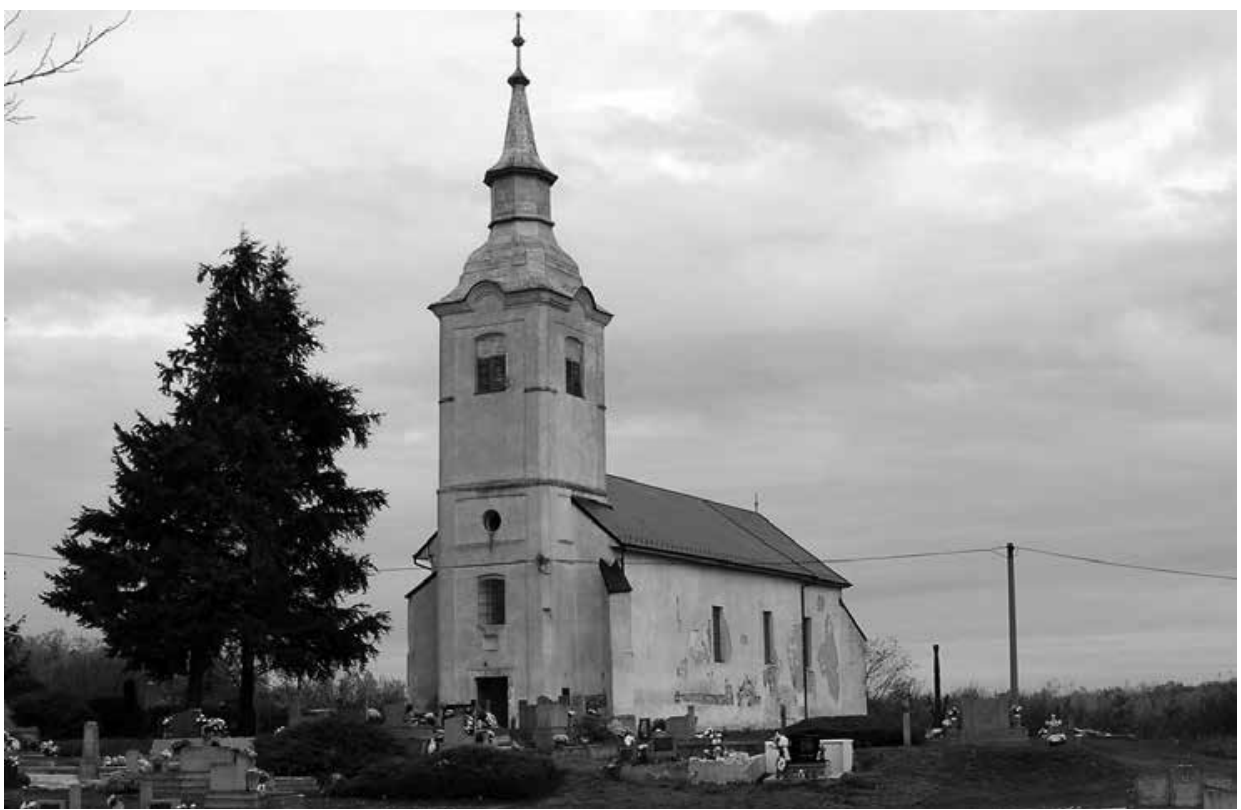

Obr. 1 Kostol reformovanej krest’anskej cirkvi v Zemplíne. Foto P. Tajkov.

Abb. 1. Kirchbau der reformierten christlichen Kirche in Zemplín. Foto P. Tajkov. 


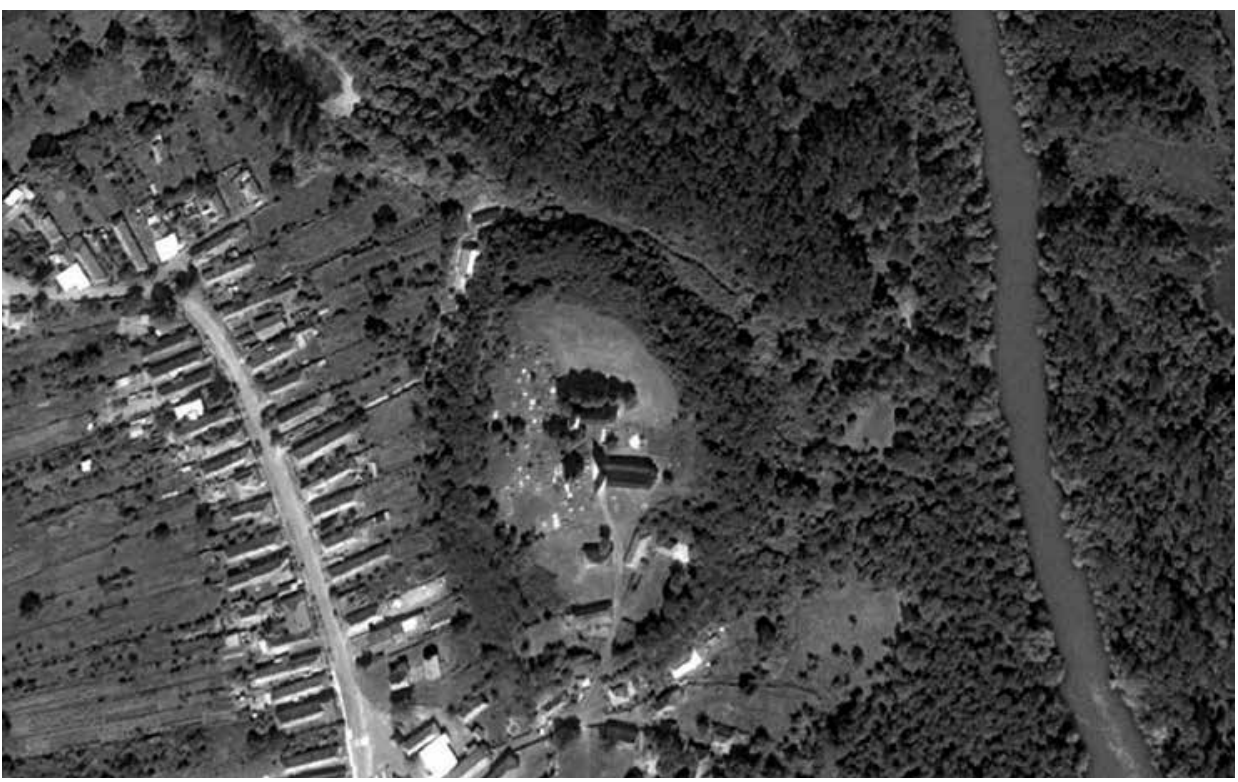

Obr. 2. Zemplínske Hradisko. Foto archív autora - zdroj GoogleEarth.

Abb. 2. Sempliner Burgwall. Foto Archiv des Verfassers - Quelle GoogleEarth.

Opevnená poloha a jej bezprostredné okolie patria k významným archeologickým lokalitám širšieho regiónu horného Potisia. Moderné bádanie tu siaha do roku 1931, kedy Hradisko podrobne zameral Štefan Janšák (1935, 70-73, mapa č. 15; obr. 3). Prvý archeologický výskum tu od roku 1955 viedol Blažej Benadik (1965, 63-91). Tento i neskoršie výskumy sa však sústredili na nálezy z obdobia tzv. kelto-dáckeho horizontu a mladšej doby rímskej, resp. z obdobia slovanskej rekonštrukcie hradiska a až na dve výnimky sa vždy jednalo o rezy valu hradiska. Tieto výnimky sú spojené práve s málo skúmanými stredovekými pamiatkami. Prvú tvorí sonda umiestnená B. Benadikom v severovýchodnom susedstve gréckokatolíckeho kostola, v ktorej zachytil murivo, interpretované ako stredoveké (Benadik 1965, 69). Druhou je sonda vo vnútri hradiska, realizovaná D. Čaplovičom v roku 1984 (Čaplovič 1985, 75-77). Na juhozápadnom okraji hradiska, v susedstve bývalej farskej školy, preskúmal pät’ hrobov, z ktorých jeden obsahoval nález esovitej záušnice z 12. storočia. Autor výskumu popísal hroby ako súčast' stredovekého cintorína, prináležiaceho k staršej, doposial' neobjavenej románskej sakrálnej stavbe.

V súvislosti s plánovanou obnovou kostola tu boli v nedávnom čase realizované dva architektonicko-historické výskumy a jeden reštaurátorský výskum. Prvý výskum prebehol v roku 2008 , kedy jeho autorka konštatovala, že celý objekt okrem veže pochádza z 15 . storočia s výraznou klasicistickou prestavbou (Čechová 2008). Ked’že tento výskum nevyriešil všetky otázky spojené s jeho plánovanou obnovou, pamiatkarmi bol iniciovaný d’alší výskum v roku 2011. Autori výskumu okrem iného posunuli jeho najstaršiu fázu už do 13. storočia, spájali ju s armovanými nárožiami v hmote dnešnej lode, interpretovanými ako zvyšky pôvodnej lode staršieho kostola (Kurthy-Glocková 2011). Rovnako spresnili datovanie výstavby polygonálneho presbytéria do prvej polovice 16. storočia a západné predíženie románskej lode datovali do druhej polovice 19. storočia. Reštaurátorský výskum interiéru, ktorý krátko predchádzal nášmu výskumu, doplnil doterajšie poznatky o objekte o hodnotný nález zamurovaného okenného otvoru v južnej stene dnešnej lode (Boroš 2013). Ide o štrbinové okno s nepravidelným oblým záklenkom a skoseným parapetom, ktoré je dnes predmetom pamiatkovej prezentácie (obr. 4). Výskum zdokumentoval aj zvyšky gotického okna s kružbou v priestore dnešnej drevenej tribúny, ktoré je v súčasnosti už zamurované. 


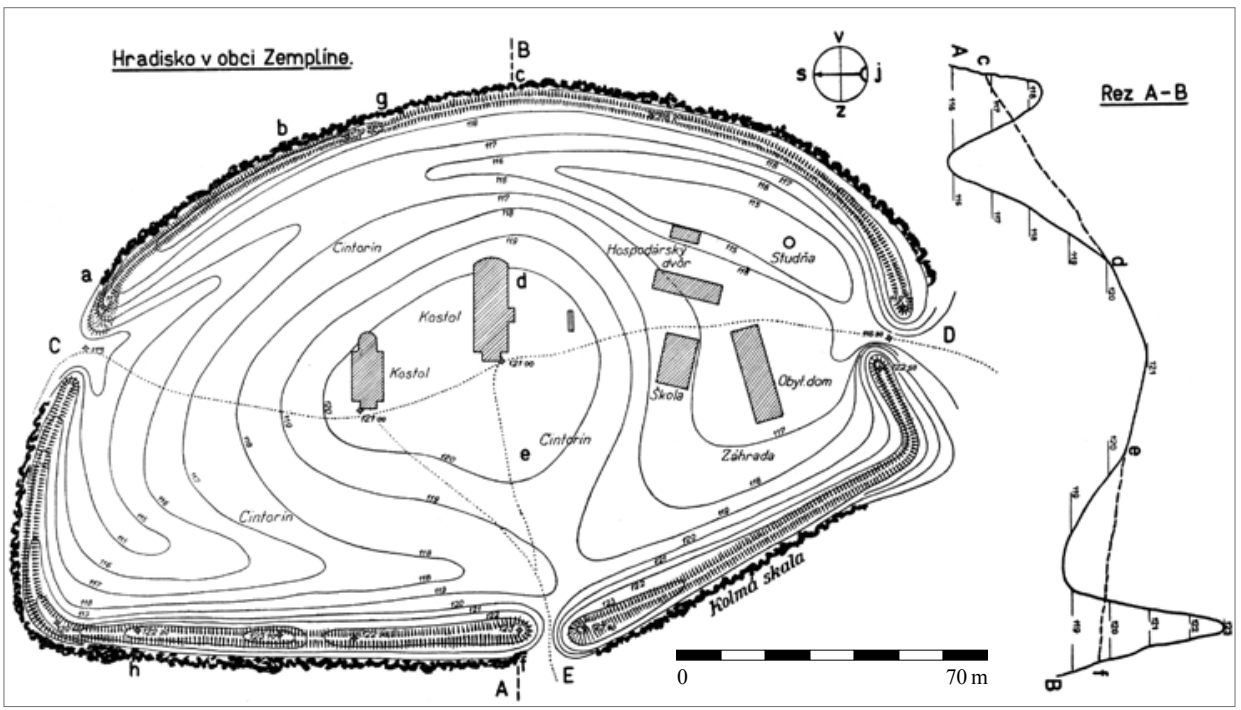

Obr. 3. Zemplínske Hradisko v zameraní Š. Janšáka z roku 1931. Podl’a Janšák 1935, mapa č. 15.

Abb. 3. Sempliner Burgwall gemäß der Vermessung von Š. Janšák aus dem Jahr 1931. Nach Janšák 1935, Karte Nr. 15.

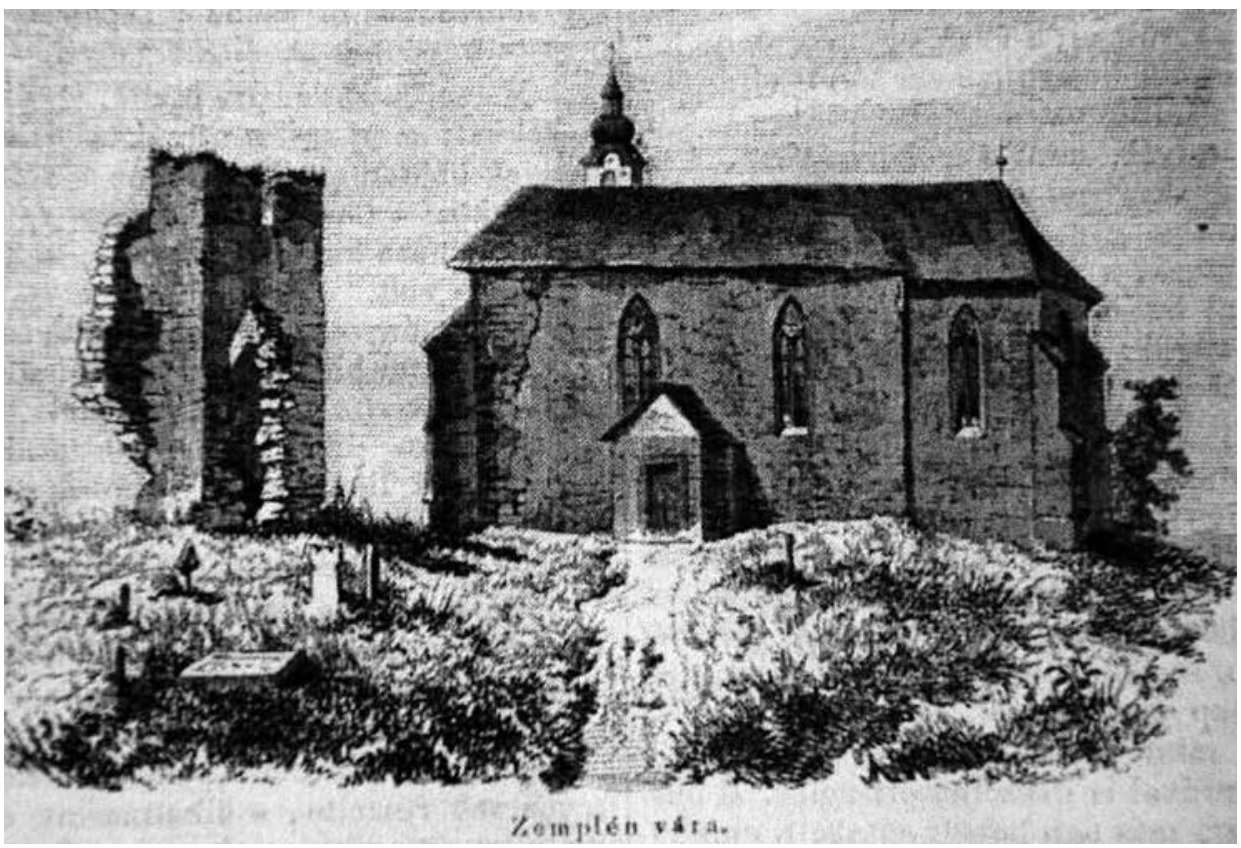

Obr. 4. Zemplínsky reformovaný kostol s ruinou hradu na kresbe z roku 1859. Podl’a VU 1859, 172.

Abb. 4. Sempliner reformierte Kirche mit Burgruine auf einer Zeichnung aus dem Jahr 1859. Nach VU $1859,172$.

História lokality je najviac poznamenaná osídlením z neskorej doby laténskej, kedy tu vzniklo keltsko-dácke hradisko s mohutnými valmi (Lamiová 1993, 11). Toto včasnohistorické osídlenie polohy tu zanechalo výrazné stopy bez ohladu na neskoršie zaujatie tejto strategickej polohy. Potvrdil to aj náš výskum, ked’ prevažnú čast' keramických nálezov tvorila práve keramika, ktorú možno označit' ako dácku. V 9. storočí bolo hradisko obnovené a v literatúre býva 
označované ako vel'komoravské, ale bádatelia zároveň pripúštajú, že z hradiska, ale ani z iných slovanských nálezísk regiónu nemáme žiadne nálezy vel'komoravskej proveniencie (ČaplovičMiroššayová 1991, 122-132; Béreš 2004, 95-96). Niektorí autori považujú príslušnost' Zemplína k tejto ríši za jednoznačný fakt (Čaplovič 1998, 147), iní za diskutabilný problém (Slivka-Vallašek 1982, 292), ba niektorí s ňou vôbec nerátajú (Třeštík 2001, 135). Vo všeobecnosti je potrebné počítat' s územnou príslušnost'ou horného Potisia $\mathrm{k}$ Vel'komoravskému štátu za jeho najväčšieho rozmachu v období panovania kniežat’a Svätopluka, konkrétnejšie však iba v krátkom období od roku 881 (Steinhübel 2004, 132-133). V samotnej obci Zemplín ilustruje následný staromad’arský vpád do Karpatskej kotliny na konci 9. storočia nález náčelníckeho hrobu v polohe Szélmalomdomb, založeného do mohyly z doby rímskej, považovaný svojho času za hrob kniežat’a Álmoša (Budínsky-Krička-Fettich 1973). Tento nález viedol N. Fetticha k domnienke, že vel'mož padol v boji o hradisko, čo naznačuje aj staromad’arská gombíkovitá nášivka, nájdená priamo vo vale (Benadik 1964, 158). Ťažko presnejšie rekonštruovat' udalosti, ktoré viedli k transformácii hradiska na mocenské stredisko uhorského král'ovstva. Svojím spôsobom to popisuje kronikár krála Bela III., ked’ spomína aj hrad Zemplín, na ktorý sa chcel pred Álmošom uchýlit' slovanský správca hradu Uh (,... fuga lapsus ad castrum Zemlun.“; Múcska 2000, 54-55). Odhliadnuc od Anonymovej literárnej fabulácie, môžeme jeho viaceré zmienky o hrade Zemplín považovat' za najstaršie písomné doklady jeho stredovekej existencie. Rovnako je však potrebné poukázat' na kontinuitu slovanského osídlenia v 10. storočí, ako to dokazuje nález polozemnice $\mathrm{v}$ polohe Kertalja (dvor bývalého JRD) s výraznou slovanskou keramikou z tohto obdobia (Lamiová 1993, 47-48). Do tohto obdobia sú datované aj najstaršie kostrové hroby z tejto polohy, avšak len jeden z nich bol orientovaný (Čaplovič-Miroššayová 1991, 122-132). V neposlednom rade bol v 10. storočí obnovený aj val hradiska, ako to zachytil B. Benadik v jeho rezoch (1965, Abb. 7).

Napriek nespornému významu lokality v rámci administratívnej správy uhorského královstva, ktorá dala názov aj samotnej župe, sú najstaršie písomné zmienky o nej pomerne chudobné. Historické pramene k stredovekému Zemplínu naposledy zhrnul F. Uličný (2001, 637-642) a tak nasledujúce dáta čerpáme z tejto práce. Najstarší priamy doklad o „castri Zemlun“ je až z roku 1219. Na konci 13. storočia hrad aj s okolím zabral palatín Omodej, avšak po konsolidácii pomerov za Karola Róberta získal hrad rod Drugethovcov, ktorý ho vlastnil až do konca stredoveku. Prudký rozvoj podhradia sa odrazil od 15. storočia v jeho označovaní ako mestečka, od polovice 17. storočia však už obec postupne upadala. Dnešný reformovaný kostol sa cez zmienku o miestnom farárovi prvýkrát spomína až v roku 1318. O význame lokality ako cirkevného centra však svedčí vznik zemplínskeho archidiakonátu, ktorý sa ale priamo spomína až v 13. storočí. V pápežských desiatkoch z 30-tych rokov 14. storočia sa dozvedáme aj o jeho pôvodnom zasvätení sv. Jurajovi (MVS I., 115). Najneskôr v roku 1598 je už v rukách reformovanej cirkvi. V roku 1628 bol kostol obnovený za údajného prispenia Gabriela Bethlena. Čo sa týka novovekej histórie hradu, ktorý v tom čase stál pravdepodobne v tesnej blízkosti kostola, v roku 1655 ho načas okupoval Juraj Rákoczi I., ale už koncom 17. storočia sa bývalé komitátne sídlo spomína ako zničené (Borovszky 1905, 138). V správe z roku 1873 sa uvádza, že kvôli stavbe veže ku kalvínskemu kostolu rozobrali asi 15 metrov vysokú ruinu hradnej veže, ktorá tam dovtedy stála (Lamiová 1993, 54). Tá je spolu s vtedajším vzhl'adom kostola vyobrazená na kresbe uverejnenej v dobových nedel'ných novinách z roku 1859 (VU 1859, 172; obr. 5).

\section{Archeologický výskum}

Výskum v interiéri realizovaný v roku 2013 bol vyvolaný obnovou, resp. výmenou podlahy kostola. V prvej fáze, pred odstránením drevenej a betónovej podlahy, sme v kostole umiestnili tri sondy. Získali sme tak základné poznatky o vertikálnej stratigrafii lokality a určité predstavy o dimenziách starších stavebných etáp kostola. Neskôr bola postupne odkrytá väčšia čast' podlahy kostola, kedy sme pokračovali odkrytím d’alších 9 sond, čo už prinieslo ucelené poznatky, najmä k pôdorysnej dispozícii najstaršej stavebnej fázy kostola (obr. 6). 


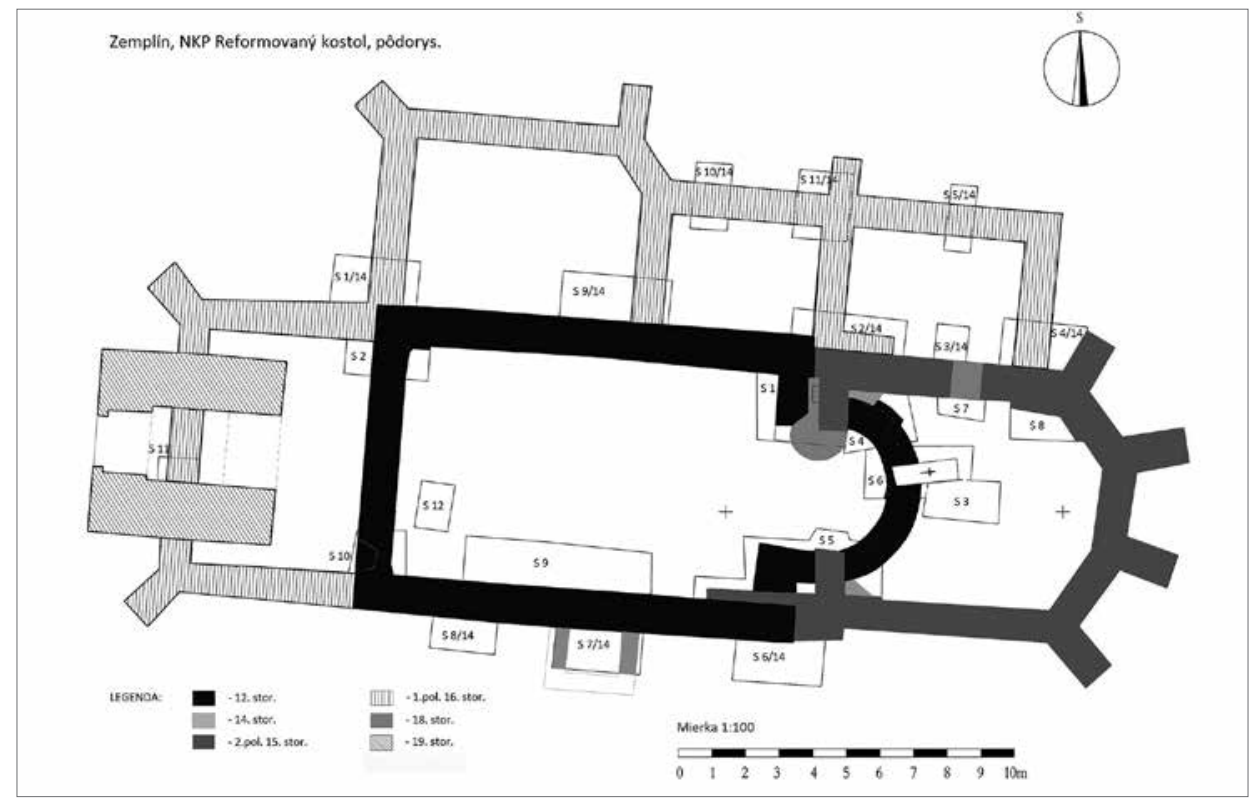

Obr. 5. Zemplín, reformovaný kostol. Pôdorys s vyznačením hlavných stavebných fáz v úrovni základov. Kresba A. Balogh. Abb. 5. Zemplín, reformierte Kirche. Grundriss mit eingezeichneten Hauptbauphasen auf Fundamentniveau. Zeichnung A. Balogh.

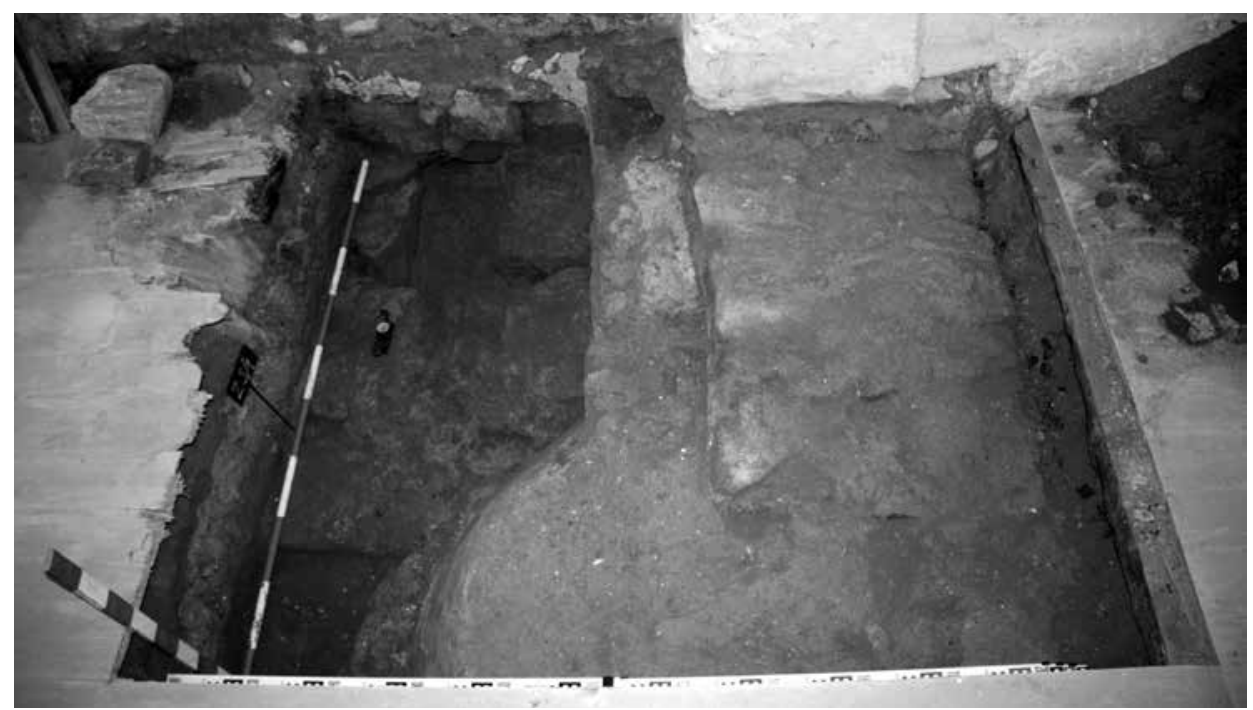

Obr. 6. Zemplín, reformovaný kostol. Sonda S1/13, základové murivá vít’azného oblúka neskorogotického presbytéria a barokovej kazatel'nice stojace na základoch apsidy románskeho kostola. Foto A. Balogh.

Abb. 6. Zemplín, reformierte Kirche. Sondierschnitt S1/13, Grundmauer des Triumphbogens des spätgotischen Chorraums und der auf den Fundamenten der Apsis der romanischen Kirche stehenden barocken Kanzel. Foto A. Balogh.

Jedná sa o murivo jednolod’ovej stavby s mierne podkovovitou apsidou. Liate základové murivo pozostáva z lomového andezitu hnedosivej farby, kladeného do riadkov, pričom nadzemné murivo je stavané $z$ hrubšie opracovaných kamenných kvádrov nepravidelnej vel'kosti. Ložná malta je tvrdá, silne vápenná sivej farebnosti s podielom vel'kých kusov drveného štrku, vápennými okami a lokálne uhlíkmi. Ako už naznačil výskum L. Kurthyho a B. Glockovej, do- 
dnes z tohto kostola stojí vel'ká čast' južného a severného múra jeho lode. Toto zistenie umocnil aj nález štrbinového okna so skoseným parapetom a nepravidelným polkruhovým záklenkom v južnej stene lode. Aj preto sme už v prvej fáze výskumu spol’ahlivo objavili zvyšky základov jeho zbúraného západného múru (S2/13), postaveného priamo na pomerne plytké skalnaté podložie temena Hradiska. Rovnako sa nám už v prvej etape podarilo zachytit’ severnú hranu oddelenia jeho lode od jeho pôvodnej svätyne (S1/13, obr. 7). Tieto zistenia sme neskôr potvrdili aj na južnej strane stavby. Zvyšky muriva jeho svätyne sme objavili až v druhej etape výskumu, kde sme dokonca v spojených sondách S4 a S6/13 objavili aj fragmenty jej nadzemného muriva, spolu so zvyškom pôvodnej podlahy kostola v podobe jej maltového lôžka (obr. 8). Murivo apsidy sa zachovalo iba po okrajoch, avšak v dostatočnej miere na to, aby sme spol'ahlivo dokázali rekonštruovat' jej tvar. Apsida bola od lode oddelená len prostou hranou, bez zvýraznenia vít’azným oblúkom. V sonde S9/13 sme identifikovali aj pôvodný južný vstup do tohto kostola s dvojnásobnou omietkovou vrstvou, avšak bez stopy po kamennom portáli. Sondou S12/13 sme sa pokúsili overit’ prípadné zvyšky piliera empory, avšak takúto zaniknutú konštrukciu tu nenaznačovala ani len väčšia koncentrácia stavebnej sutiny. Jednalo sa teda o relatívne vel'ký kostol s dížkou $16,5 \mathrm{~m}$ a šírkou niečo cez $9 \mathrm{~m}$, s pomerne plytkou, mierne podkovovitou apsidou $\mathrm{s}$ vnútornou svetlostou $3,5 \mathrm{~m}$.

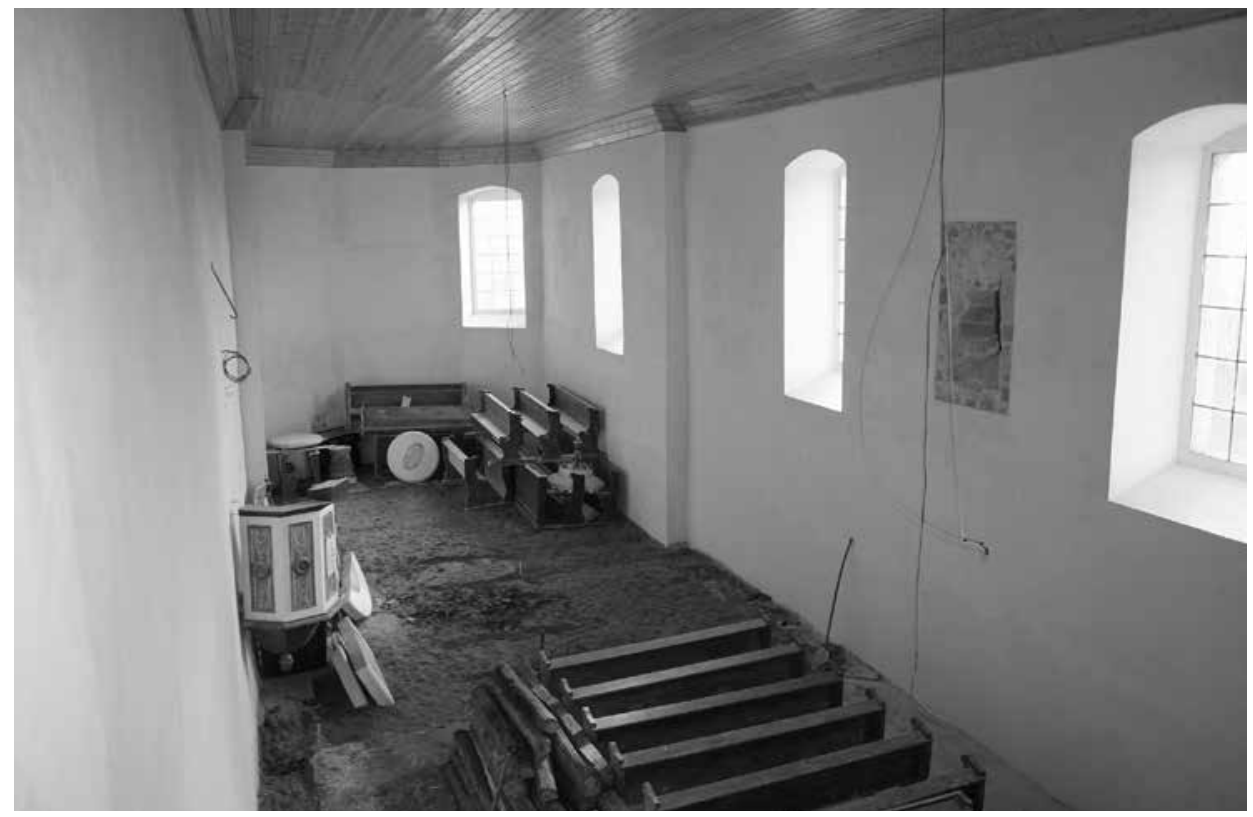

Obr. 7. Zemplín, reformovaný kostol. Stav interiéru na začiatku druhej etapy archeologického výskumu v roku 2013. Foto A. Balogh.

Abb. 7. Zemplín, reformierte Kirche. Zustand des Innenraums zu Beginn der zweiten Grabungsetappe im Jahr 2013. Foto A. Balogh.

Na základe dokumentovania stratigrafie skalnatého podložia, na ktorom spočívajú základy pôvodného kostola, môžeme konštatovat', že boli postavené na východnom okraji pôvodne strmého, azda aj bralnatého svahu zvažujúceho sa k rieke Bodrog, resp. k valu hradiska. Pokial' sa $\mathrm{v}$ lodi toto podložie nachádza $\mathrm{v}$ híbke približne jedného metra od dnešnej podlahy $(119,28 \mathrm{~m}$ n.m. v S1/13, 119,08 v S2/13), tak v tesnom exteriéri pôvodnej apsidy sa nachádza až v híbke bezmála $2,5 \mathrm{~m}(117,79 \mathrm{v}$ S3/13). Táto skutočnost' mohla mat' za následok statické problémy pôvodnej svätyne, s čím pravdepodobne súvisia fragmenty muriva primurované po stranách apsidy. Interpretujeme ich ako zvyšky jej neskoršieho oporného systému, ktoré vznikli azda až po zovšeobecnení tzv. oporného systému u nás, najskôr koncom 13. storočia. 


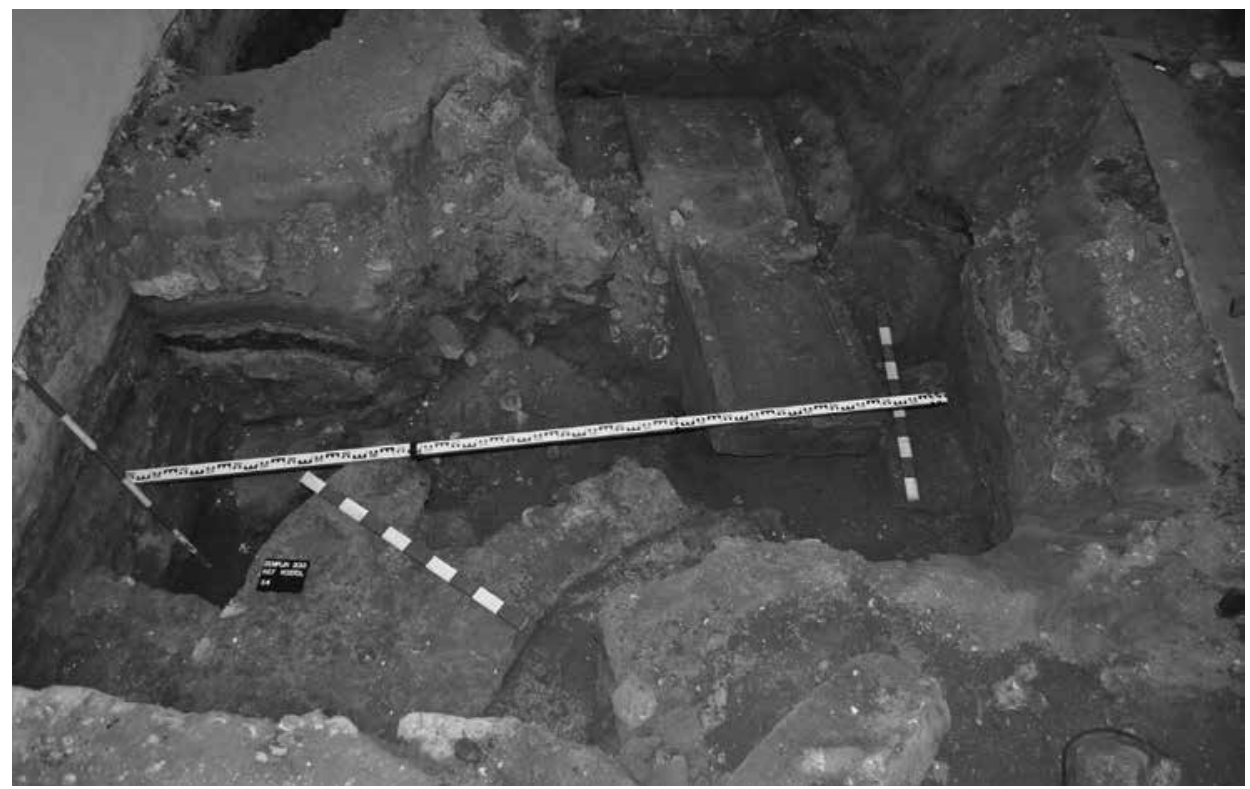

Obr. 8. Zemplín, reformovaný kostol. Sondy S4 a S6/13, základové murivo apsidy a náhrobná platňa z roku 1600. Foto A. Balogh. Abb. 8. Zemplín, reformierte Kirche. Sondierschnitte S4 und S6/13, Grundmauer der Apsis und Grabplatte aus dem Jahr 1600. Foto A. Balogh.

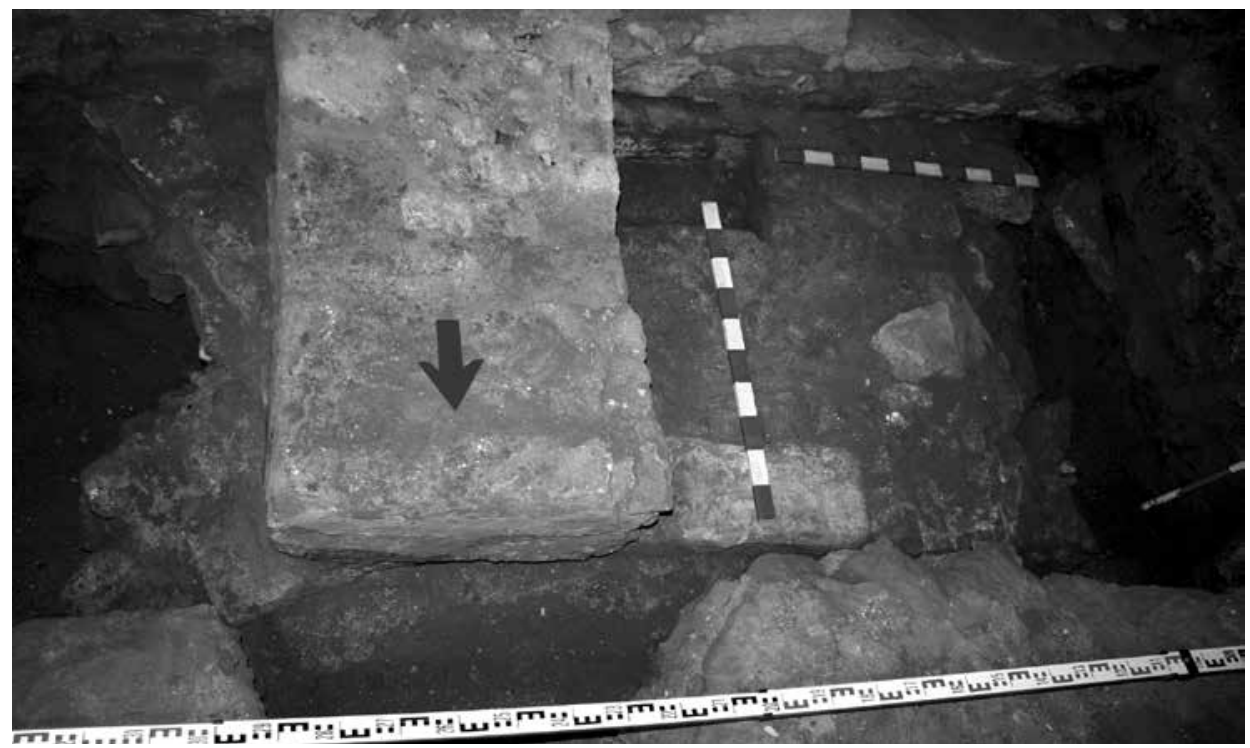

Obr. 9. Zemplín, reformovaný kostol. Sonda S5/13, základové murivo vít’azného oblúka neskorogotického presbytéria stojace na základoch apsidy románskeho kostola. Foto A. Balogh.

Abb. 9. Zemplín, reformierte Kirche. Sondierschnitt S5/13, Grundmauer des Triumphbogens des auf den Fundamenten der Apsis der romanischen Kirche stehenden spätgotischen Chorraums. Foto A. Balogh.

Výraznou stavebnou úpravou, podl'a predpokladu L. Kurthyho a B. Glockovej, prešiel kostol na sklonku stredoveku. Zbúraná bola románska apsida a nahradilo ju dlhé polygonálne presbytérium s opornými piliermi. Z tejto fázy sa dodnes čiastočne zachovali okenné otvory kostola (na viacerých miestach architektonickým a reštaurátorským výskumom objavené ich 
pôvodné parapety a záklenky). Archeologickým výskumom sme objavili základy jeho, dnes už zaniknutého, vít’azného oblúka, z vel'kej časti spočívajúce na základoch bývalej apsidy (obr. 6 a 9). Ide o kamenné murivo z lomových kameňov, spájané mäkkou drolivou, okrovohnedou maltou s výrazným podielom bielych vápenných granuliek. O niečo neskôr bola románska lod' predížená západným smerom, čo okrem iného dokladá zamurované neskorogotické okno v južnej stene tohto predíženia, ale i nárožné oporné piliere dostavby. Výskumom sme zachytili čast' jej zaniknutého západného uzáveru $\mathrm{v}$ dnešnej veži kostola. $\mathrm{V}$ juhovýchodnom rohu tejto lode sme objavili aj schod k vel'kej, dnes už zamurovanej sedílii. S ciel'om overit' prípadnú stavebnú medzifázu presbytéria (jeho rovný uzáver) sme otvorili sondu v severnom rohu dnešného polygónu (S8/13). Žiadne zaniknuté murivo sme tu však neobjavili, napriek tomu sme mali možnost' opät' dokumentovat' pomerne prudké zvažovanie pôvodného terénu smerom na východ. Základy svätyne sú tu o bezmála 1,5 metra hlbšie ako jej základy pri vít’aznom oblúku. Tomu nasvedčuje aj hrubá vrstva hlinitej homogénnej navážky, ktorá vznikla v snahe stavitel’ov vyrovnat' prirodzený sklon svahu. V tejto stavebnej etape bol pravdepodobne zamurovaný románsky južný vstup do kostola a o niečo východnejšie bol prerazený väčší vstupný otvor, ktorý slúžil až do prvej polovice 20. storočia.

Snád' niekedy v období baroka bola pri severnom pilieri neskorogotického vítazného oblúka vybudovaná, rovnako už dnes zaniknutá, kazatel'nica, o ktorej svedčia jej oválne základy (obr. 6). K nej sa viazala aj posledná historická dlážka tvorená lomovým andezitom v maltovom lôžku.

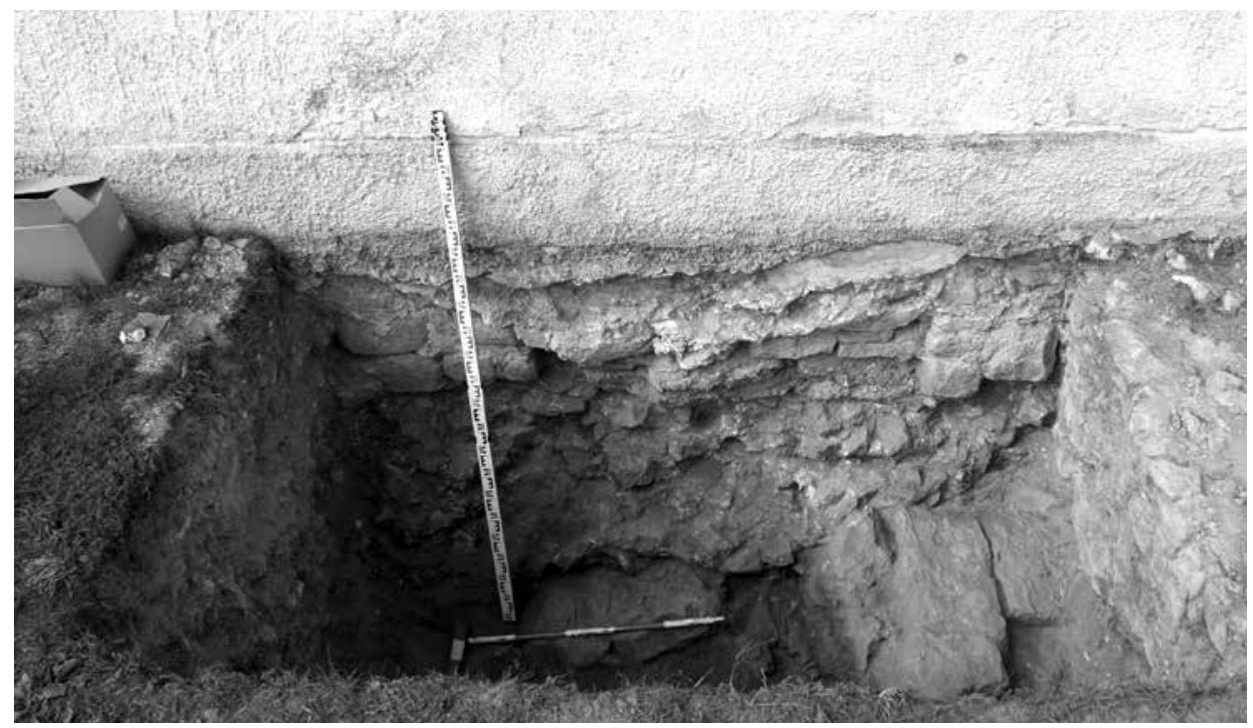

Obr. 10. Zemplín, reformovaný kostol. Sonda S7/14, základové murivo románskeho kostola a tzv. babinca stojace na skalnom geologickom podloží v miestach prerazeného gotického vstupu do kostola. Foto A. Balogh.

Abb. 10. Zemplín, reformierte Kirche. Sondierschnitt S7/14, Grundmauer der romanischen Kirche und des am durchbrochenen gotischen Eingang zur Kirche auf einer Felssohle stehenden sog. „Babinec“ (Frauen vorbehaltener Raum). Foto A. Balogh.

Záverečnú etapu výstavby kostola tvorí mohutná západná veža z roku 1872 , ktorej sa náš výskum dotkol len okrajovo, so zistením, že čiastočne stojí na základoch západnej steny neskorogotickej prístavby (S11/13).

Čo sa týka nami preskúmaného pochovávania $\mathrm{v}$ interiéri kostola, $\mathrm{v}$ priestore presbytéria sa našli pozostatky niekol'kých hrobov bez sprievodných nálezov. Dokladom mladšieho pochovávania je nález náhrobnej kamennej dosky istého Georgia Feiesa (1540 - 4. máj 1600) s tzv. sikulským znakom - hviezdou a polmesiacom v kruhu. 


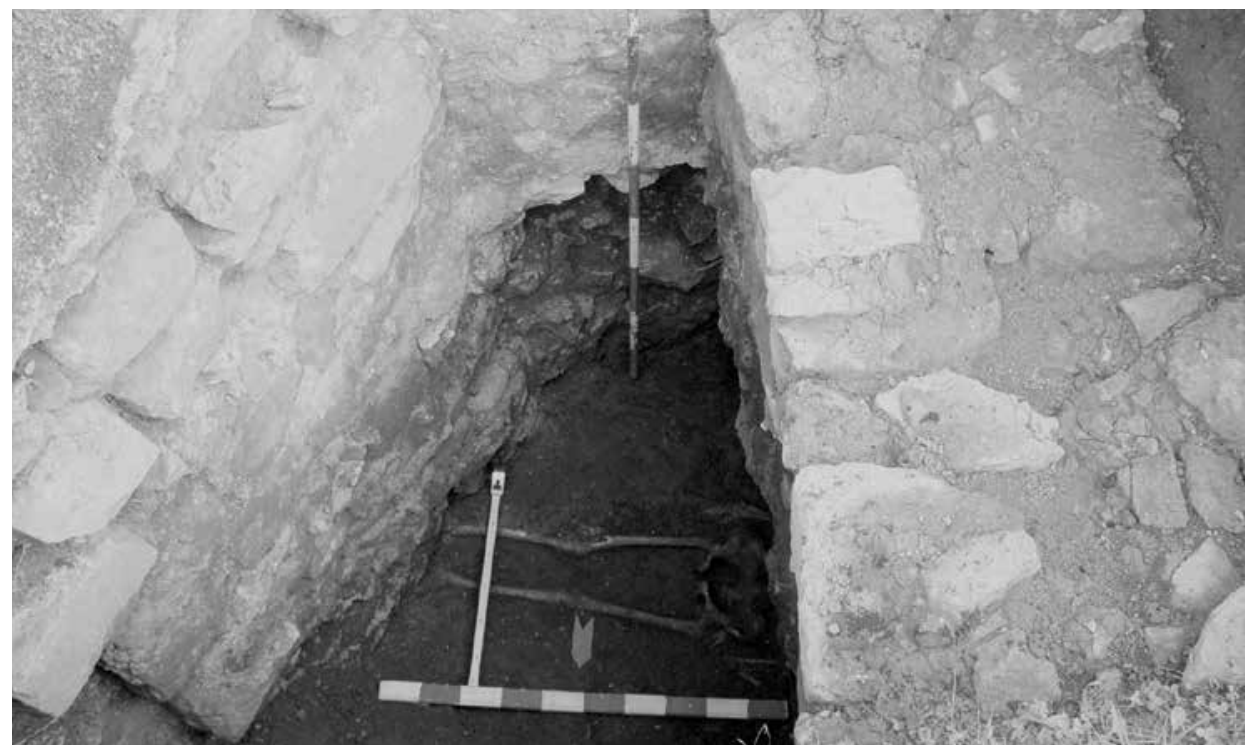

Obr. 11. Zemplín, reformovaný kostol. Sonda S4/14, hrob v superpozícii so základovými murivami oporného piliera presbytéria a sakristie. Foto A. Balogh.

Abb. 11. Zemplín, reformierte Kirche. Sondierschnitt S4/14, Grab in Superposition mit Grundmauer eines Stützpfeilers von Chorraum und Sakristei. Foto A. Balogh.

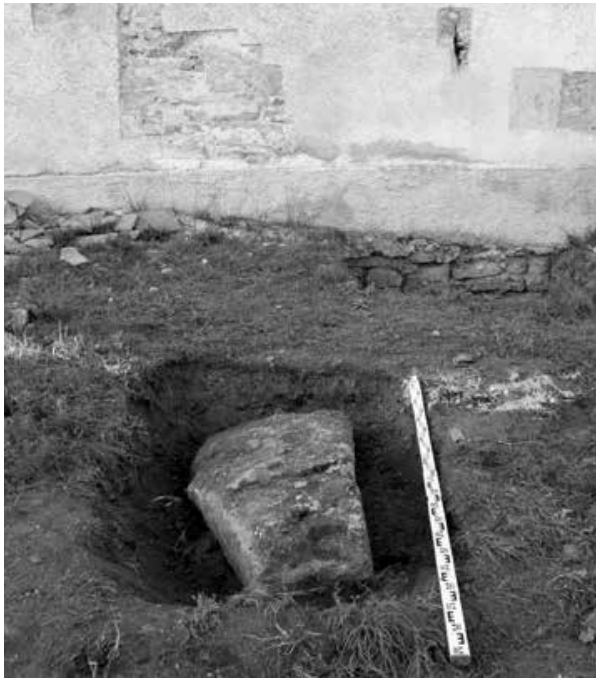

Obr. 12. Náhrobný kameň pri južnom múre kostola. Foto A. Balogh

Abb. 12. Grabstein an der Kirchensüdmauer. Foto A. Balogh.
V roku 2014 prebehla d'alšia výskumná etapa, už výhradne $\mathrm{v}$ exteriéri. Výskum bol vyvolaný snahou vlastníka upravit', resp. znížit' terén okolo kostola, najmä na jeho severnej strane. Jedným z našich výskumných ciel'ov bolo pokúsit' sa aj o zachytenie starších hrobov prikostolného cintorína, ktoré by nám mohli spresnit' počiatky výstavby kostola. Ukázalo sa však, že hroby v bezprostrednej blízkosti stavby boli porušené mladšími zásahmi. Zachytili sme tak len fragmenty hrobov, resp. l'udských kostier a jeden hrob v superpozícii s murivom zaniknutej sakristie (obr. 11). Opät' však bez sprievodných hrobových nálezov, a to ani v sekundárnych polohách.

Výskum exteriéru však výrazne doplnil naše doterajšie poznatky o stavebnej histórii kostola. Na južnej strane lode, pri bývalom gotickom južnom vstupe to boli zvyšky babinca aj s jeho kamennou dlažbou, ktorý tu stál ešte $\mathrm{v}$ prvej polovici 20. storočia. Aj v týchto miestach bolo základové liate murivo románskeho kostola postavené priamo na skalnom podlo-
ží, nachádzajúcim sa len ca $1 \mathrm{~m}$ od pôvodnej úrovne terénu (obr. 10). Ovel’a intenzívnejšia bola stavebná činnost' na severnej strane kostola. V sonde S1/14 sme zachytili murivo pristavané k pôvodnému severozápadnému nárožiu románskeho kostola, avšak previazané s jeho neskorogotickou západnou prístavbou. Po následnom plošnom odkryve humusovej vrstvy sa ukázalo, že sa pôvodne jednalo o mohutnú neskorostredovekú severnú prístavbu s opornými piliermi, rozdelenú na tri samostatné priestory (obr. 13). Západný priestor - kaplnka so skoseným náro- 
žím a vnútornou svetlost'ou ca $7 \times 5 \mathrm{~m}$ - bol pôvodne otvorený do lode kostola azda arkádou, ako o tom svedčí chýbajúce kvádrikové murivo v jej severnej stene. V strednom, najmenšom priestore s vnútornou svetlost'ou ca $5 \times 4 \mathrm{~m}$ sme zachytili aj fragmenty jeho dlážky tvorené tehlovými dlaždicami $(20 \times 20 \times 4 \mathrm{~cm})$ so skosenou hranou. Východný priestor, pristavaný už k polygonálnemu presbytériu kostola, možno interpretovat' ako sakristiu. Už v roku 2013 sme v interiéri preskúmali prah jej vstupu, prerazeného do steny presbytéria. Celá severná prístavba pravdepodobne zanikla už na konci 17. storočia, v súvislosti so zničením hradu.

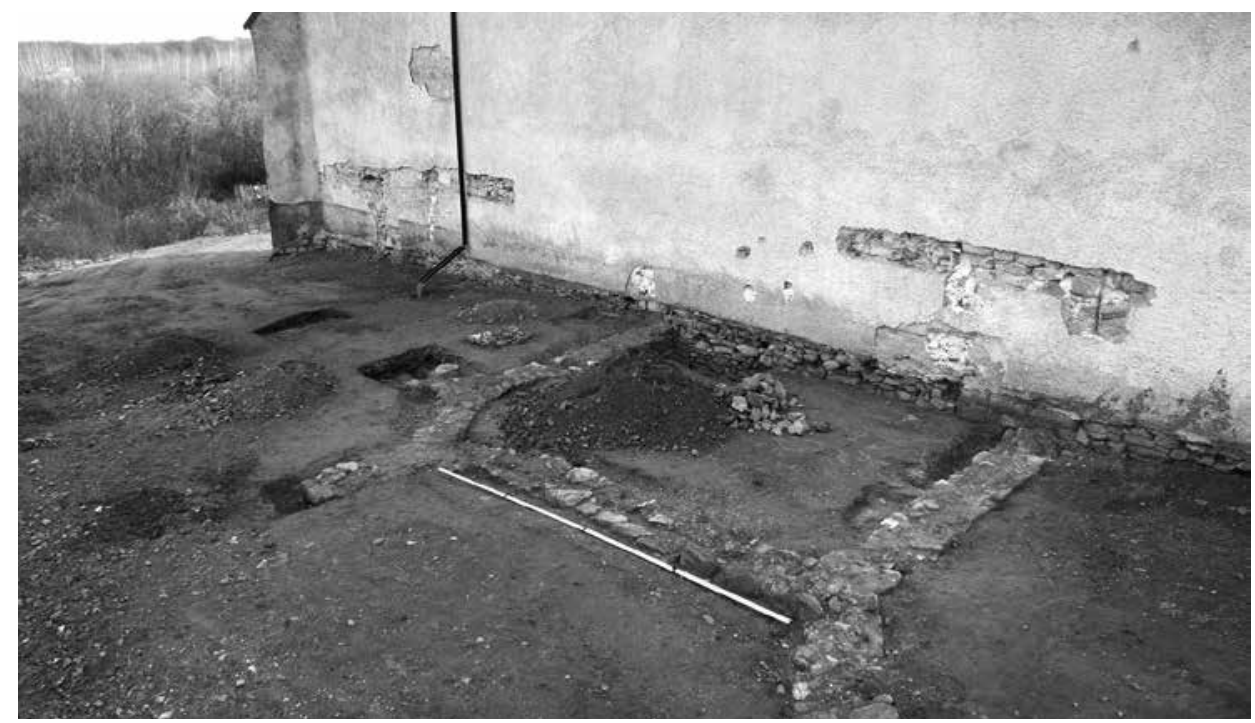

Obr. 13. Zemplín, reformovaný kostol. Základové murivá severnej neskorogotickej kaplnky. Foto A. Balogh. Abb. 13. Zemplín, reformierte Kirche. Grundmauer der im Norden gelegenen spätgotischen Kapelle. Foto A. Balogh.

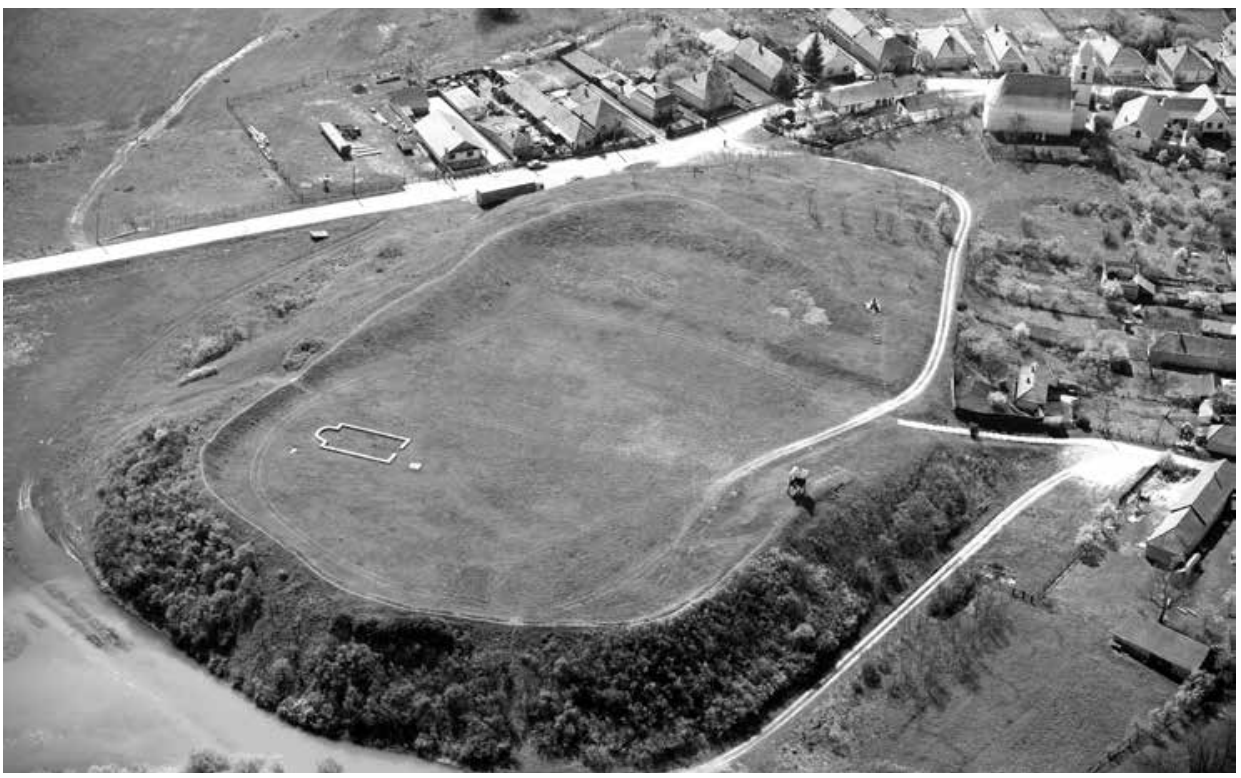

Obr. 14. Hradisko v Borsode (HU). Foto archív autora.

Abb. 14. Grundriss der Überreste der Kirche in Borsod. Foto Archiv des Verfassers. 


\section{Záver}

Románsky Kostol sv. Juraja na zemplínskom Hradisku, na mieste dnešného reformovaného kostola, už v minulosti predpokladali viacerí bádatelia (Slivka-Vallašek 1991, 233; Lamiová 1993, 53). Túto hypotézu však potvrdili až posledné výskumy, z ktorých archeológia nakoniec priniesla pomerne ucelený obraz o jeho pôdorysnej dispozícii. Zvyšky a samotný tvar pôvodnej svätyne totiž poskytujú isté možnosti spresnenia jeho datovania. Zatial' čo nález do vel'kej miery zachovaného muriva lode tohto kostola viedol L. Kurthyho a B. Glockovú k jeho datovaniu len širšie do 13. storočia, polkruhová až mierne podkovovitá apsida posúva toto datovanie určite pred polovicu tohto storočia. Zároveň, vzhl'adom na písomnými prameňmi odôvodnený predpoklad existencie komitátneho sídla na Hradisku už okolo roku 1200 možno s výstavbou Kostola sv. Juraja rátat' najneskôr v závere 12. storočia. Označenie románsky kostol však možno prijat' iba s výhradami spojenými s minimálnymi možnost’ami jeho štýlovej analýzy. To však platí v celom kontexte najstaršej sakrálnej architektúry na hornom Potisí. Formy vrcholného románskeho slohu (v špecifikách východnej periférie jeho rozšírenia) tu napĺn̆a iba niekol'ko stavieb z obdobia medzi polovicou 12. storočia a začiatkom 13. storočia - v kontraste s pestrým a širokým okruhom neskororománskych kostolov tu budovaných až do konca 13. storočia (Tajkov 2012, 237).

Žial', náš výskum nepriniesol presnejší datovací materiál, najmä hrobové celky viažuce sa $\mathrm{k}$ počiatkom jeho výstavby. Zdá sa, že staršie hroby sa zachovali neporušené mladším cintorínom iba $\mathrm{v}$ juhozápadnom priestore hradiska, kde bol ca $60 \mathrm{~m}$ od kostola objavený spomínaný hrob s esovitou záušnicou z 12. storočia. Stopy staršieho pochovávania pri kostole však dokladá hrubo opracovaný náhrobný kameň pri jeho južnom múre, ktorý sa nachádzal tesne pod trávnatou vrstvou (obr. 12). Tieto kamene sa u nás vyskytujú hlavne v 11.-13. storočí, resp. do začiatku 14. storočia (Hanuliak 1979, 167-186). Na druhej strane je potrebné poukázat' na pomerne plytkú úroveň skalného podložia (ca $1 \mathrm{~m}$ ), dokumentovanú naším výskumom na viacerých miestach, ktoré mohlo determinovat' pochovávanie na vrchole Hradiska.

Objav zvyškov kostola na zemplínskom Hradisku tak doplnil obraz o najstaršej sakrálnej architektúre včasnouhorských komitátnych centier severovýchodnej časti bývalého král'ovstva. Okolo roku 1000 obnovili pôvodne slovanské hradisko Boršod na sútoku Slanej a Bodvy (Wolf 1992, 393-431). Dodnes mohutné zemné opevnenie sa spája s menom Boršu, považovaného za

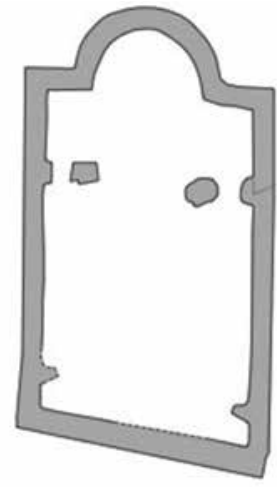

Wellovica 12. storotia Borsod (M)

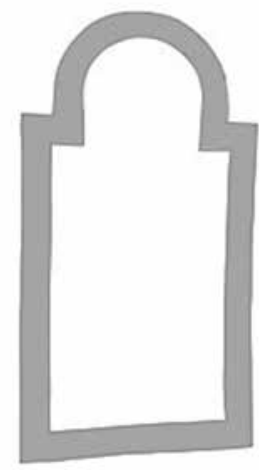

Eillokolo roku 1100 Abaújuar (K)

Obr. 14a. Pôdorys zvyškov kostola v Borsode. Podl’a Wolf 2005. Abb. 14a. Burgwall in Borsod (Ungarn). Nach Wolf 2005. Obr. 14c. Pôdorys zvyškov kostola v Abaújvári. Podl’a Gádor 1980 .

Abb. 14c. Grundriss der Überreste der Kirche in Abaújvár. Nach Gádor 1980 .

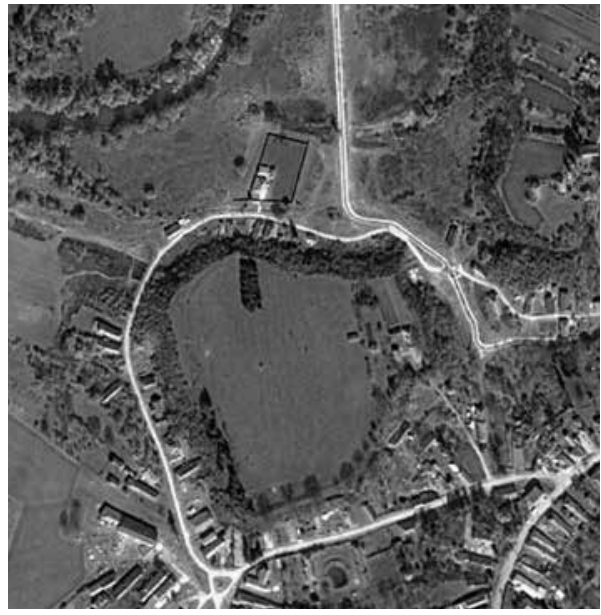

Obr. 14b. Hradiskov Abaújvári (HU). Foto archiv autora - zdroj GoogleEarth.

Abb. 14b. Burgwall in Abaújvár (Ungarn). Foto Archiv des Verfassers - Quelle GoogleEarth. 
najstaršieho člena rodu Miškovcov - predstavitel'ov pôvodnej slovanskej aristokracie, neskôr spríbuznenej s Arpádovcami (Steinhübel 2004, 217). Základy pomerne vel'kého kostola s polkruhovou apsidou, ktoré tu boli objavené, sú datované do polovice 11. storočia (Wolf 2005, 131-139; obr. 14, 14a). Približne v tom čase bolo severnejšie, na terase Hornádu, vybudované d’alšie komitátne hradisko Abaújvár (Gádor-Nováki 1976, 44-45). Kamenný kostol tu bol postavený na prelome 11. a 12. storočia, zachovaný bol však, podobne ako v Boršode, len v základoch (Gádor 1980, 443-454; Wolf 2001, 182; obr. 14b, 14c). V rámci horného Potisia bol spomedzi kostolov vybudovaných vo včasnouhorskom období pri zemných hradoch pravdepodobne najreprezentatívnejší kostol v Szabolcsi, na pravom brehu Tisy a na hranici bývalej Zemplínskej a Szabolcskej župy. Zvyšky pôvodne trojlod’ovej baziliky stoja čiastočne dodnes na jeho juhovýchodnom vonkajšom okraji (Németh 1976). Tieto kostoly tak tvorili základnú kostru novovznikajúcej cirkevnej organizácie severovýchodného konfínia král’ovstva prvých Arpádovcov. Kým však spomínané kostoly postupne zanikali, resp. upadali spolu so zemnými hradiskami už koncom 13. storočia, zemplínsky kostol prežíval ešte na sklonku stredoveku obdobie vel'korysých úprav. Zaiste to súvisí aj s výstavbou kamenného hradu, ktorý tu s vel'kou pravdepodobnostou vznikol už v 12. storočí a je pre archeológiu stále otvorenou výzvou.

\section{Pramene a literatúra}

BENADIK, B., 1964: Slovanské nálezy z výskumu valu na Hradisku v Zemplíne, ŠZ AÚ SAV 14, 151-160. - 1965: Die spätlatènezeitliche Siedlung von Zemplín in der Ostslowakei, Germania 43, 63-91.

BÉREŠ, J., 2004: Včasný stredovek. In: Gačková, L., Archeologické dedičstvo Zemplína - Pravek až včasný stredovek, 96-97, 520. Michalovce.

BOROŠ, R., 2013: Dokumentácia vykonaných reštaurátorských prác realizovaných v interiéri ref. kostola v obci Zemplín, rkp. nálezovej správy ulož. v Krajskom pamiatkovom úrade v Košiciach, č. 1581/2013.

BOROVSZKY, S., 1905: Magyarország Vármegyéi és városai - Zemplén vármegye. Budapest.

BUDÍNSKY-KRIČKA, V.-FETTICH, N., 1973: Das altungarische Fürstengrab von Zemplín. Bratislava.

ČAPLOVIČ, D., 1985: Výsledky výskumu hradiska v Zemplíne. In: AVANS 1984, 75-77. Nitra.

- 1998: Včasnostredoveké osídlenie Slovenska. Bratislava.

ČAPLOVIČ, D.-MIROŠŠAYOVÁ, E., 1991: Najnovšie výsledky výskumu včasnodejinného a stredovekého osídlenia v Zemplíne, Východoslovenský pravek 3, 122-132.

ČECHOVÁ, J., 2008: Architektonicko-historický a umelecko-historický výskum reformovaného kostola v Zemplíne, rkp. nálezovej správy ulož. v Krajskom pamiatkovom úrade v Košiciach, č. T-1293.

GÁDOR, J., 1980: Ausgrabung in der Erdburg von Abaújvár. Eine Kirche in der Gespanschaftsburg, Acta Archeologica Academiae Scientarum Hungaricae 32, 443-454.

GÁDOR, J.-NOVÁKI, G., 1976: Ásatás az abaújvári földvárban, Herman Ottó Múzeum évkönyve XV, $37-50$.

HANULIAK, M., 1979: Hroby pod náhrobnými kameňmi v 11.-14. storočí, SlArch XXVII, 167-186.

JANŠÁK, Š., 1935: Praveké sídliská s obsidiánovou industriou. Bratislava.

KURTHY, L.-GLOCKOVÁ, B., 2011: Architektonicko-historický výskum reformovanej krestanskej cirkvi v Zemplíne, rkp. nálezovej správy ulož. v Krajskom pamiatkovom úrade v Košiciach, č. 673/2012.

LAMIOVÁ, M., 1993: Zemplín - obec s bohatou minulostou. Košice.

MÚCSKA, V., 2000: Kronika anonymného notára krála Bela. Gesta Hungarorum. Budmerice.

MVS: Monumenta Vaticana Slovaciae. Tomus 1. Rationes collectorum pontificiorum in annis 1332-1337. (Sedlák, V., ed.). Trnavae - Romae 2008.

NÉMETH, P., 1976: Ásatási jelentés. Szabolcs - Ref. Parókia 1975, Magyar Nemzeti Múzeum Adattár XIV., č. 122.

SLIVKA, M.-VALLAŠEK, A., 1982: Hospodárske zázemie šlachtických sídiel v oblasti horného Zemplína, AH 7, 289-310.

- 1991: Hrady a hrádky na východnom Slovensku. Košice.

STEINHÜBEL, J., 2004: Nitrianske kniežatstvo. Bratislava.

SÚPIS, 1969: Súpis pamiatok na Slovensku III. Bratislava.

TAJKOV, P., 2012: Sakrálna architektúra 11.-13. storočia na juhovýchodnom Slovensku. Košice.

TŘEŠTÍK, D., 2001: Vznik Velké Moravy. Moravané, Čechové a střední Evropa v letech 791-871. Praha.

ULIČNÝ, F., 2001: Dejiny osídlenia Zemplínskej župy. Michalovce. 
VU, 1859: Zemplén vára. Vasárnapi Ujság 15. Pest.

WOLF, M., 1992: Előzetes jelentés a borsodi földvár ásatásáról. (1987-1990), A nyíregyházi Jósa A. Múzeum évk. 30-32, 393-431.

- 2001: Északkelet-Magyarország ispáni várai, Herman Ottó Múzeum évkönyve XL, 179-198.

- 2005: Ecclesia baptismalis, ecclesia parochialis. A borsódi ispánsági vár templomai. In: Ritoók, Á.-Simonyi, E., A középkori templom körüli temetők kutatása. Opuscula Hungarica 6, 131-139. Budapest.

\section{Zusammenfassung}

\section{Die archäologische Grabung in der reformierten Kirche auf dem Sempliner Burgwall}

Die reformierte Kirche der Gemeinde Zemplín (Semplin) befindet sich an deren östlichem Rand am rechten Ufer des Flusses Bodrog auf einer Anhöhe namens Hradisko (Burgwall). Die befestigte Lage und ihre unmittelbare Umgebung zählt zu den bedeutenden archäologischen Fundstellen der breiteren Region Oberes Theiß-Gebiet. Die Geschichte der Fundstelle ist am meisten durch seine Besiedelung in der Spätlatènezeit gezeichnet, als dort ein keltisch-dakischer Burgwall mit mächtigen Wällen entstanden war, der von den Slawen im 9. und 10. Jahrhundert wieder aufgebaut wurde. Später wurde der Burgwall zu einem Verwaltungszentrum des frühungarischen Staates, konkret des Komitats Semplin. Die untersuchte reformierte Kirche steht ungefähr in der Mitte des ehemaligen Burgwalls. Sie wurde erst im Jahr 1318 zum ersten Mal erwähnt und war ursprünglich dem Hl. Georg geweiht. Durch die in den Jahren 2013 und 2014 durchgeführten archäologischen Grabungen wurde der Grundriss der Kirche und ihre älteste Bauphase aus dem 12. Jahrhundert rekonstruiert. Dabei handelte es sich um eine einschiffige Kirche mit leicht hufeisenförmiger Apsis, von welcher sich bis heute große Teile des Kirchenschiffmauerwerks erhalten haben. Im 15. Jahrhundert wurde die Apsis durch einen polygonalen Chorraum ersetzt, dessen Schiff zu Beginn des 16. Jahrhunderts in westliche Richtung erweitert wurde. In jenem Zeitraum wurde an der Nordseite eine heute nicht mehr existierende Kapelle und eine Sakristei angebaut. Ende des 19. Jahrhunderts wurde der Kirchturm errichtet. Der Fund der ursprünglichen St. Georgskirche auf dem Sempliner Burgwall ergänzt das Bild von der ältesten Sakralarchitektur in den frühungarischen Komitatzentren im nordöstlichen Teil des mittelalterlichen ungarischen Königreichs wie es Abaújvár, Borsod und das heute in Ungarn liegende Szabolcs waren.

Mgr. Peter Tajkov, PhD., Fakulta umení Technickej univerzity v Košiciach, Letná 9, SK 04200 Košice, tajkov@yahoo.co.uk 
